\title{
Review A Trending and Interesting Topic of 'Aloe Vera: Healthy Lifestyle Trends Through Functional Food Consumption' in Science Learning
}

\author{
Djuniar Rahmatunnisa Haristy ${ }^{1,{ }^{*}}$ I Gusti Putu Suryadarma ${ }^{2,}$ Khoirul Huda ${ }^{1,}$ Puji \\ Rahayu $^{1}{ }^{1}$ Nedia Erlini ${ }^{1}$
}

\author{
${ }^{1}$ Master of Natural Science Education, Faculty of Mathematics and Natural Sciences, Universitas Negeri \\ Yogyakarta, Indonesia \\ ${ }^{2}$ Department of Biology Education, Faculty of Mathematics and Natural Sciences, Universitas Negeri Yogyakarta, \\ Indonesia \\ *Corresponding author.Email: djuniarrahmatunnisaharisty@gmail.com
}

\begin{abstract}
Increasing the community's welfare affects lifestyle changes, especially patterns of food consumption in a negative direction on the increase of degenerative diseases. The community then realized that the magnitude of the relationship between food and the risk of disease. Fact, the primary function of food is not just to provide a feeling of fullness, but more than that. Foods that have varied nutritional content will have an impact on health maintenance. Digestive organs that function correctly cause the body's metabolism to work correctly so that ultimately the primary purpose of food is to maintain survival for a healthier life that is better and free from disease. The concept of food as 'medicine' is what is currently known as a functional food. Aloe Vera is a plant with a variety of nutritional content that can maintain health and prevent disease. Science learning is very closely related to daily life, so integrating Aloe vera content as functional food into science material is certainly very beneficial for students. The integration can be carried out on the material of the Human Digestive System. The research result as an alternative teaching material to realize and train students' thinking skills about understanding the importance of consuming functional food to maintain health and prevent diseases, especially those related to the digestive canal as immunity to the body.
\end{abstract}

Keywords: Aloe vera, Functional food, Food consumption, Science learning

\section{INTRODUCTION}

Abundant biological resources make Indonesia one of the world's countries known as Mega biodiversity, with a wealth of $17 \%$ of the number of species in the world and tropical forests covering an area of 120.35 million hectares. The biodiversity is a wealth of the Indonesian nation that is priceless [1]. The specific natural wealth of plants has the potential to be developed as a medicinal plant published 30,000 plant species from a total of about 40,000 plant species in the world, and 940 species are medicinal plants. Medicinal plants contain medicinal properties that can relieve pain, increase endurance, kill germs, and repair diseased organs. Management and development of plants into food that is suitable for consumption in daily life is a form of public attention and awareness of the importance of food that does not need to be filling but is beneficial for improving good health as a disease.

Food policy is basically an important thing that is our shared responsibility as the Indonesian nation. The purpose of the policy is to be independent and national food security so that there will be a sense of commitment in the nation to maintain the vision for the availability of food needs. Indonesia's involvement proves sincerity to be one of the countries that signed the Rome Declaration on "World Food Security and World Food Summit 1996" along with 186 other countries. This declaration discusses the notion of the right to food, "Food is a basic human need whose 
fulfill is Human Rights" [2]. Human Rights through healthy living behavior should be a habit to become a good culture in living everyday life. Healthy living habits will be better if it is planted to children from an early age to imprint and continue to stick in their memories until adulthood. Healthy life behavior is an activity carried out by someone both directly and indirectly to maintain and improve health to prevent disease risk.

Furthermore, the Ministry of Health of the Republic of Indonesia states that someone who lives a healthy lifestyle will avoid health problems both physical and non-physical. The formation of a healthy living culture is not only done in the home environment but also in the school environment. Healthy living can be achieved through the consumption of healthy, nutritious, and balanced food. Nutritious, healthy food is food that is hygienic, nutritious, and does not cause disease with balanced nutrition by the amount and composition needed by the body. The body needs balanced nutrition for the process of growth and development, health maintenance, and activities. The nutritional content in a balanced diet that the body needs includes carbohydrates, protein, fat, vitamins, and mineral [3]. The body's need for nutrition is not balanced with what is consumed, then health problems will occur.

This research was conducted as a form to provide knowledge about the importance of eating healthy and nutritious foods, in line with the program carried out by the government, namely efforts through approaches to food and nutrition issues according to the Ministry of National Development Planning which in this study fulfills two points namely (1) increasing knowledge, skills, and attitudes as well as changes in the behavior of food consumption society towards increasingly diverse, healthy, nutritious and balanced food consumption; (2) the application of a clean and healthy life behavior policy with guidance starting from the household and its internalization in the education curriculum in primary and secondary schoolsreducing unhealthy food by switching to functional food so that changes in behavior or culture of food consumption towards healthy and nutritionally balanced food is one way of healthy living in order to meet nutritional needs and improve certain physiological functions. Aloe vera can be processed into functional food because it has much nutritional content outside the necessary nutrients that regulate a person's physiological functions [4]. It is just that aloe vera cannot be consumed directly because the sap (mucus) surrounding the part of the gel contains poison, so it needs special processing into food to be consumed.
The term functional food just that functional food has been studied at the level of pure food science, while learning is relatively rarely done in the world of education. One way to live healthily is to reduce unhealthy food by switching to functional food. Trends in developing regional local ingredients as functional foods with primary, secondary, and tersier functions are to meet nutritional needs and improve specific physiological processes. As one of the foodstuffs found in many regions, Aloe Vera has ingredients and benefits that meet the functional food requirements. Science learning is closely related to daily life, so integrating Aloe Vera content as functional food into natural science material is undoubtedly beneficial for students. Thus, it is necessary to develop teaching materials that integrate functional food content based on Aloe Vera materials to introduce students to the local natural materials they have to open students' minds about healthy lifestyles by utilizing the wealth of natural resources. Thus students have the provision of knowledge in terms of exploring and developing their natural wealth.

\section{RESEARCH METHOD}

This study is a literature review about Aloe Vera as a functional food that can be used as an alternative teaching material integrated into science learning. The integration can be done on the Human Digestive System material, which contains sub-chapters of nutrition, organs, and digestive system also disorders and diseases of the digestive system. This is based on Competency Standards or Basic Competencies, which are interpreted as minimum standards rather than maximum standards, so teachers are allowed to provide the expansion and deepen the concepts needed by students to obtain specific competencies for daily life. One of the expansion and deepening of students' material in solving everyday problems is the mastery of the concept of nutrition. Expansion of this concept to enrich student's nutritional knowledge and realize more real participation as an effort to realize a government program that is to improve and improve the quality of healthy life related to eating habits [5]. Basic Competence referred to is 3.5 analyzing the digestive system in humans and understands disorders related to the digestive system, as well as efforts to maintain the health of the digestive system.

The importance of comprehending the concept of nutrition to students is to train them with nutritional problems related to daily life, which is not only regionally but even globally. As an example, today there are global health problems related to lifestyles and poor food consumption patterns recommend Aloe 
Vera as a functional food containing bioactive compounds that are good for maintaining health and stimulating immunity [6]. This study aims to sensitize and train students' thinking ability about understanding the importance of consuming functional food to maintain health and prevent diseases, especially those related to the digestive tract as immunity to the body. This literature review is also expected to motivate teachers to develop other environment-based teaching materials in order to achieve quality learning.

\section{RESULT AND DISCUSSION}

Contextual learning can be implemented by integrating science learning with the daily lives of learners (contextual) using local material [7]. Implementing the 2013 curriculum requires much attention, one of which concerns the diversity of potentials and characteristics of the region, the environment, national unity, and living values. Education is directed to build living values and nationality insight of students, which are an essential foundation for maintaining national unity and integrity within the framework of the Unitary Republic of Indonesia [8].

Based on the study of the above problems about the importance of healthy food consumption patterns, one of the government's efforts, especially at the secondary education unit level, is to integrate functional food content that is good for health, especially digestion, with the school curriculum. This content integration is in the form of knowledge about the importance of knowing good food sources and their impact on health in everyday life so that there is a change in behavior or culture of food consumption towards healthy and nutritiously balanced food. Aloe vera as functional food with science material of the Human Digestive System in Basic Competencies 3.5 analyzing the digestive system in humans and understanding disorders related to the digestive system, as well as efforts to maintain the health of the digestive system. Subtopics in this material include nutrition, digestive organs, digestive system, and disorders of the digestive organs. The integration of Aloe vera as functional food on the concept of science is seen in table 1.

Table 1. Integrating aloe vera as functional food in the concept of natural sciences

\begin{tabular}{|l|l|}
\hline \multicolumn{1}{|c|}{ The concept of science } & \multicolumn{1}{c|}{ Aloe vera as a functional food } \\
\hline The nutrition & $\begin{array}{l}\text { The nutritional content of Aloe vera, which varies as functional food, fulfill } \\
\text { necessary and additional nutrients as good nutrition for health }\end{array}$ \\
\hline $\begin{array}{l}\text { The structure and function of the } \\
\text { human digestive system }\end{array}$ & $\begin{array}{l}\text { The presence of nutrients (mostly enzymes) in Aloe vera as functional food } \\
\text { facilitates the food metabolism system, which causes digestion to be healthy } \\
\text { so that it can absorb nutrients more optimally to support the body's immunity }\end{array}$ \\
\hline $\begin{array}{l}\text { Disorders of the digestive system efforts to prevent or treat it } \\
\text { and }\end{array}$ & $\begin{array}{l}\text { Knowing food that has the potential as a functional food is beneficial in } \\
\text { The nutritional content of Aloe Vera as functional food nourishes the digestive } \\
\text { tract so that in addition to maintaining health, it also alleviates diseases of the } \\
\text { digestive tract }\end{array}$ \\
\hline
\end{tabular}

Sub-chapter material on the Human Digestive System is divided into 3 , namely nutrition; structure and function of the human digestive system; on the digestive system, and efforts to prevent or overcome it. The explanation regarding the relationship between the IPA concept and the content of Aloe vera as a functional food is described as follows:

\subsection{The nutrition}

The name Aloe Vera comes from the Arabic "Alloeh" or the Hebrew language "Halal," which means that it is a shiny bitter substance [9]. Aloe vera in Indonesia, known as "lidah buaya" is a plant that belongs to the Liliaceae group [10]. This plant has physical characteristics, namely thick fleshy leaves, long, spear-shaped, sharp-pointed (narrowed to the tip), serrated leaves, green and slimy [11]. Initially, this plant originated from Africa, but now it can grow in hot, dry regions in Asia, Europe and America. Some 
sources state that Aloe Vera entered Indonesia brought by farmers of Chinese descent in the 17th century at that time, the utilization and cultivation were still limited. In 1990 farmers in West Kalimantan began commercially operating aloe Vera plants which were processed into aloe Vera drinks. Currently, aloe Vera plants have been widely developed and cultivated in Indonesia, but what is known as the centre of aloe Vera is West Kalimantan. This plant has long been known for its use as a medicinal plant for various diseases.

The raw mass part of Aloe Vera contains much nutritional value in the form of active ingredients, so it is good for health. Part of aloe Vera, which is beneficial for health, can be obtained from the leaves, exudate (gum from the gel which is yellow, thick, and bitter), and gel (the slimy part). The components contained in aloe Vera are mostly water reaching $99.5 \%$ with total dissolved solids only $0.49 \%, 0.067 \%$ fat, $0.043 \%$ carbohydrate, $0.038 \%$ protein, and the remaining vitamins, minerals, amino acids, enzymes, polysaccharide compounds, organic acids that are soluble in water and not the sea in water [12]. Soluble food fiber is useful for lowering cholesterol and improving blood lipid profile, preventing obesity, preventing diabetes, and reducing coronary heart disease risk. Meanwhile, insoluble dietary fiber can increase fecal water content and as a development agent, thereby facilitating feces' disposal. This can also shorten the contact of toxic compounds against the walls of the colon (large intestine) and then the concentration of these toxic compounds to prevent colon cancer [13]. There are more than 350 types of Aloe Vera, but some of the most popular commercial types include Aloe barbadensis miller and Aloe arborescens. Commercial types planted in Aloe vera West Kalimantan center are Aloe chinensis baker and Aloe barbadensis miller [14].

It is just that the food consumed undoubtedly not only provides a feeling of fullness, but must meet health requirements and contain sufficient nutrients, so that the body's metabolism can function properly. The nutrients needed by the body every day contain at least carbohydrates, fats, protein, vitamins, minerals, and water and fiber to help smooth the metabolic process. These nutrients are the necessary nutrients needed by the body to carry out life [15].

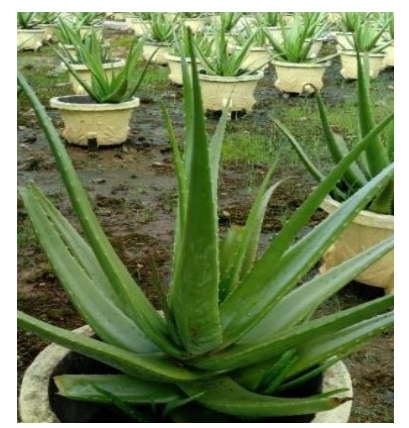

Figure 1 Aloe vera plant (Source: personal doc.)

Aloe Vera can be consumed by processing it into foods that are beneficial to health, including nata de aloe, syrup, tea, juice, jelly, and aloe vera jam. Aloe Vera fulfills the body's necessary nutrients as presented in Table 2 adapted from [16], [17].

The food industry utilizes aloe vera to produce it as a functional food, especially health drinks [18]. The International Aloe Science Council has developed a validation program for the quality and quantity of aloe vera for approved commercial products. The term functional food was initially introduced in Japan in the early 1980s, which refers to processed foods with ingredients that have beneficial effects on the human body's physiological functions, namely maintaining and improving health [19]. Regulation of the Head of BPOM RI Number HK 00.05.52. 0685, 2005 states that functional food can be processed foods containing one or more functional components that, based on scientific studies, have certain physiological functions and are proven to be harmless and beneficial to health. Meanwhile, according to the Dallas USA Functional Food Centre (FFC) in the 17th International Conference 2014 states that functional food is natural or processed foods containing bioactive compounds that are not toxic in quantities that are effective when consumed, clinically proven and have health impacts for prevention, maintenance or treatment of chronic diseases [20]. The conclusion, functional food has 3 benefits at once, namely primary, secondary and tertiary. The primary benefit is meeting humans' basic nutritional needs in terms of carbohydrates, proteins, fats, vitamins, and minerals. Secondary because the human sense of taste can accept the food in good taste and attractive appearance. Tertiary as prevention or minimize disease with active ingredients contained in it. 
Table 2. Fulfillment of aloe vera content as basic nutrition for the body

\begin{tabular}{|c|c|c|}
\hline Nutrition & Type & Nutritional content \\
\hline \multicolumn{3}{|r|}{ Metabolic primer } \\
\hline \multirow[t]{3}{*}{ Carbohydrate } & Monosaccharide & Glucose \\
\hline & Disaccharide & Fructose \\
\hline & Polysaccharide & $\begin{array}{l}\text { Glucomannan, arabinan, arabinorhamnogalactan, glactan, } \\
\text { galactogalacturan, glucogalactomanan, glucuronat acid, selulose, } \\
\text { manosa, L-rhamnose and aldopentose. }\end{array}$ \\
\hline \multirow[t]{3}{*}{ Protein } & Amino acid & $\begin{array}{l}\text { Non-essential: histidine, arginine, hydroxyproline, aspartate acid, } \\
\text { glutamate acid, proline, glisin and alanine }\end{array}$ \\
\hline & & $\begin{array}{l}\text { Essential: lysine, threonine, valine, leucine, isoleucine, phenylalanine, } \\
\text { and methionine }\end{array}$ \\
\hline & Enzym & $\begin{array}{l}\text { Aliase, alkali fosfatase amylase, catalase, peroxidase, lipase, } \\
\text { carboxypeptidase, cyclooxygenase, and oxidase }\end{array}$ \\
\hline Fat & Sterol & Campestrol, cholesterol, $\beta$-sitosterol, lupeol \\
\hline Vitamin & & $\begin{array}{l}\text { Vitamin A ( } \beta \text {-carotene), vitamin B (B1, B2, B6, choline, folate acid), } \\
\text { vitamin C (ascorbate acid), and vitamin E ( } \alpha \text {-tocopherol) }\end{array}$ \\
\hline Mineral & & $\begin{array}{l}\text { Zinc }(\mathrm{Zn}) \text {, calcium }(\mathrm{Ca}) \text {, copper }(\mathrm{Cu}) \text {, magnesium }(\mathrm{Mg}) \text {, manganese } \\
(\mathrm{Mn}) \text {, sodium }(\mathrm{Na}) \text {, chlorine }(\mathrm{Cl}) \text {, chromium }(\mathrm{Cr}) \text {, dan iron }(\mathrm{Fe})\end{array}$ \\
\hline \multicolumn{3}{|l|}{ Water } \\
\hline \multicolumn{3}{|r|}{ Metabolic sekunder } \\
\hline Anthraquinone & & $\begin{array}{l}\text { Aloe-emodin, aloetik acid, anthranol, aloin A dan B, isobarbaloine, } \\
\text { emodin, ester from sinamat acid, anthranol, chrysophanic acid, } \\
\text { anthracene, resistanol and ether oil }\end{array}$ \\
\hline
\end{tabular}

\subsection{The Structure and Function of the Human Digestive System}

Aloe vera enters the oral cavity and is subjected to mechanical digestion, namely chewing, mixing, and kneading with the help of teeth, tongue, and salivary glands. The amylase enzyme in Aloe vera helps break down large molecules into small ones so that the digestive products in the oral cavity called the bolus will pass through the pharynx (pharynx) to the esophagus (esophagus). The peristalsis on the esophagus helps push the bolus into the stomach. The stomach stirs the bolus with gastric juice (hydrochloric acid $(\mathrm{HCl})$, pepsinogen enzymes, renin enzymes, and mucosa (mucus)). Protein will be hydrolyzing into peptone (a mixture of polypeptides and amino acids). The presence of essential and non-essential amino acids in Aloe Vera makes it easier for the stomach to digest. After 2-4 hours of digestion in the stomach, the bolus will become kimus (yellowish intestinal pulp). As a result of peristaltic movements, the sphincter relaxes in a concise time, so that the chymus is pushed gradually into the duodenum.

In the duodenum, the duct empties the pancreas and bile duct. The pancreas produces pancreatic juice, which contains the enzymes lipase, amylase, and trypsin. Lipase enzymes will digest fat into fatty acids and glycerol. Amylase digests starch into glucose, and trypsin will digest protein into polypeptides (various amino acids). Aloe vera contains lipase and amylase enzymes that will help speed up the process of digestion of food. So, in the duodenum, the whole process of digestion of carbohydrates, fats, and proteins is completed. The final stage of food digestion is continued in the jejunum, before finally becoming a readily digested substance in the ileum. Vitamins and minerals do not undergo digestion and can be directly absorbed by the small intestine. Glucose molecules, water-soluble vitamins, amino acids, and minerals will be absorbed by the small intestinal villi and carried by the blood to the liver and circulated throughout the 
body. Glucose in the liver is then stored in the form of glycogen as muscle sugar. Fat-soluble fatty acids, glycerol, and fat-soluble vitamins after being absorbed by the small intestinal villi are carried by the lymph vessels to the liver and then stored in fat tissue.

The amount of water content in Aloe vera helps the digestive and metabolic processes of the body. Glucomannan found in Aloe vera is a hemicellulose component in the cell wall that functions as food fiber. The presence of fiber can stimulate the digestive tract's activity to facilitate the process of removing digestive waste. Food ingredients that reach the large intestine can be said to be leftover substances that are not digested in the small intestine. The waste substance consists of a large amount of water along with fiber and mucus, which will go to the large intestine to become feces. Before being discharged through the anus, the feces are accommodated in the rectum and then go to the anus, which is the hole where the feces are discharged from the body.

\subsection{Disorders of The Digestive System and Efforts to Prevent or Overcome Them}

Disturbances in the digestive system are related to the nutritional content of the body's intake every day. The nutritional content of various types of Aloe vera is an example of foods that can be good for health, especially the digestive tract. Moreover, these nutrients have a good function in preventing and treating diseases, anti-viral and anti-bacterial such as dental caries, ulcers, diarrhea, constipation, and against various types of other digestive tract diseases. Aloe vera contains which has the potential as a functional food. In detail, the nutrients contained in Aloe vera related to digestive disorders are as follows:

a. The low carbohydrate content is safe for consumption for diabetics and obesity

b. Fiber is suitable for diet and smoothes the drainage of food waste, digestive debris is not too in the large intestine, which can cause the body to be poisoned. Besides, dietary fiber absorbs much water, making food softer and easier to digest

c. Mineral vitamins prevent vitamin-mineral deficiency

d. Water reduces plaque sticking to the teeth causing dental caries, preventing constipation

Related to the benefits of aloe vera in maintaining health and treating diseases that occur, especially the digestive tract as follows: a. Cure hemorrhoids, which are swollen blood vessels that cause pain and bleeding in the anal shaft. The content of active substances in laxative aloe vera can launch bowel movements.

b. Adjust the acidity of the peat associated with heartburn

c. Increase the work of the stomach

d. Suppress intestinal microorganism populations

e. Eliminates constipation and sores in the intestinal wall

Literacy on the importance of maintaining the body's digestive system through consuming foods that are nutritious and can also prevent and treat diseases in the current era is necessary. This function of Aloe vera is known as a functional food. The importance of maintaining digestive health is the principal capital to maintain body immunity.

\section{CONCLUSION}

The integration of Aloe vera content as functional food can be implemented in science learning on the subject of the Human Digestive System. An explanation of Aloe vera's content as functional food can be discussed in each sub material like nutrition, organs and digestive system and disorders/diseases of the digestive tract. Teachers can increase students' knowledge about the importance of eating healthy foods that are nutritious to maintain the body's health and strengthen immunity to avoid disease.

\section{ACKNOWLEDGMENTS}

The author would like to thank LPDP, which had provided both material and moral assistance for the author to carry out studies and conduct research.

\section{REFERENCES}

[1] R.A. Putra, Wiryono, E. Apriyanto, Studi Etnobotani Suku Serawai di kelurahan Sukarami Kecamatan Selebar Kota Bengkulu, Naturalis: Jurnal Penelitian Pengelolaan Sumber Daya Alam dan Lingkungan 1(3) (2012) 217-224.

[2] World Food Summit, Rome Declaration on world Food Security, Food and Agriculture Organization, Nov. 1996. Accessed on: Feb. 2, 2020. [Online]. Available: http://www.fao.org/3/w3613e/w3613e00.htm

[3] A.L. Astuti, Early Children's Healthy Behavior, Indonesian Journal of Early Childhood Education 
Studies 6(1) (2017) 16-21. DOI: https://doi.org/10.15294/ijeces.v6i1.15778

[4] Y. S. K. Dewi, Tranggono, S. Raharjo, P. Hastuti, Aktivitas Antioksidasi Ekstrak Aloe Vera sebagai Penangkap Radikal, Agritech 25(3) (2005) 124130.

DOI:

https://doi.org/10.22146/agritech.13346

[5] M. Nurjhani, N.Y. Rustaman, S. Redjeki, Kajian tentang Penguasaan Konsep Gizi Siswa SMP, Jurnal Pendidikan IPA Indonesia 1(2) (2012) 149-156.

DOI: https://doi.org/10.15294/jpii.v1i2.2132

[6] P. Chand, N. Pandey, B. Naik, A. Sinh, V. Kumar, Application of Aloe vera for The Development of Functional Foods, The Pharma Innovation 8(5) (2019) 621-625.

[7] I. Wilujeng, Z.K. Prasetyo, I.G.P. Suryadarma, Science learning based on local potential: Overview of the nature of science (NoS) achieved, in: AIP Conference Proceedings, vol. 1868, AIP Publishing, College Park, Maryland, 2017, pp. 1-7. DOI: https://doi.org/10.1063/1.4995189

[8] F.M. Sya'ban, I. Wilujeng, Pengembangan SSP Zat dan Energi Berbasis Keunggulan Lokal untuk Meningkatkan Literasi Sains dan Kepedulian Lingkungan, Jurnal Inovasi Pendidikan IPA 2(1) (2016) 66-75. DOI: https://doi.org/10.21831/jipi.v2i1.8369

[9] B. Joseph, R.J. Raj, Pharmacognostic and Phytochemical Properties of Aloe Vera Linn -An Overview, International Journal of Pharmaceutical Sciences Review and Research 4(1) (2010) 106-110. DOI: https://doi.org/10.5958/2321-5844.2017.00004.8

[10] S. Moghaddasi, S.K. Verma, Aloe Vera Their Chemicals Composition and Application: A Review, International Journal of Biological and Medicinal Research 2(1) (2011) 466-471.

[11] K. Manvitha, B. Bidya, Aloe Vera: A Valuable Wonder Plant for Food, Medicine and Cosmetic Use - A Review, International Journal of Pharmaceutical. Sciences Review and Research 13(1) (2012) 59-67.

[12] Hernawati, W. Manalu, A. Suprayogi, D.A. Astuti, Suplementasi Sera Pangan Karagenan dalam Diet untuk Memperbaiki Parameter Lipid Darah Mencit Hiperkolesterolemia, Makara Seri
Kesehatan 17(1) (2013) 1-9. DOI: https://doi.org/10.7454/msk.v17i1.2004

[13] M. Astawan, A.E. Febrinda, Potensi Dedak dan Bekatul Beras sebagai Ingredient Pangan dan Produk Pangan Fungsional, Pangan 19(1) (2010) 14-20.

DOI: https://doi.org/10.33964/jp.v19i1.104

[14] T.Y. Hendrawati, Aloe Vera Powder Properties Produced from Aloe Chinensis Baker, Pontianak, Indonesia, Jornal of Engineering Science and Technology 10(1) (2015) 47-59.

[15] N.A. Campbell, Biology, 2003.

[16] K.B. Bhuvana, N.G. Hema, R.T. Patil, Review on Aloe Vera, International Journal of Advanced Research 2(3) (2014) 677-691.

[17] S.B. Sanghi, Aloe Vera: A Medicinal Herb, International Journal of Research-Granthaalayah 3(11) (2015) 32-34.

[18] C.E. Turner, D.A. Williamson, P.A. Stroud, D.J. Talley, Evaluation and Comparison of Commercially Available Aloe Vera L. Products Using Size Exclusion Chromatography with Refractive Index and Multi-Angle Laser Light Scattering Detection, International Immunopharmacology 4(14) (2004) 1727-1737. DOI:

https://doi.org/10.1016/j.intimp.2004.07.004

[19] M. Shimizu, Functional Food in Japan: Current Status and Future of Gutmodulatin Food, Journal of Food and Drug Analysis 20(1) (2012) 213216. DOI: https://doi.org/10.38212/22246614.2093

[20] D.M. Martirosyan, J. Singh, A New Definition of Functional Food by FFC: What Makes A New Definition Unique?, Functional Food in Health and Disease 5(6) (2015) 209-223. DOI: https://doi.org/10.31989/ffhd.v5i6.183 